\title{
Legal Protection Of Broker Company's Customers Against Commodity Futures Trading In Review Of Law Number 10 Year 2011 (Case Study Of PT. Kontak Perkasa Future)
}

\section{Rahmat Ari Septiawan}

Sumatera University Faculty Of Law. E-mail: rahmatseptiawan@gmail.com

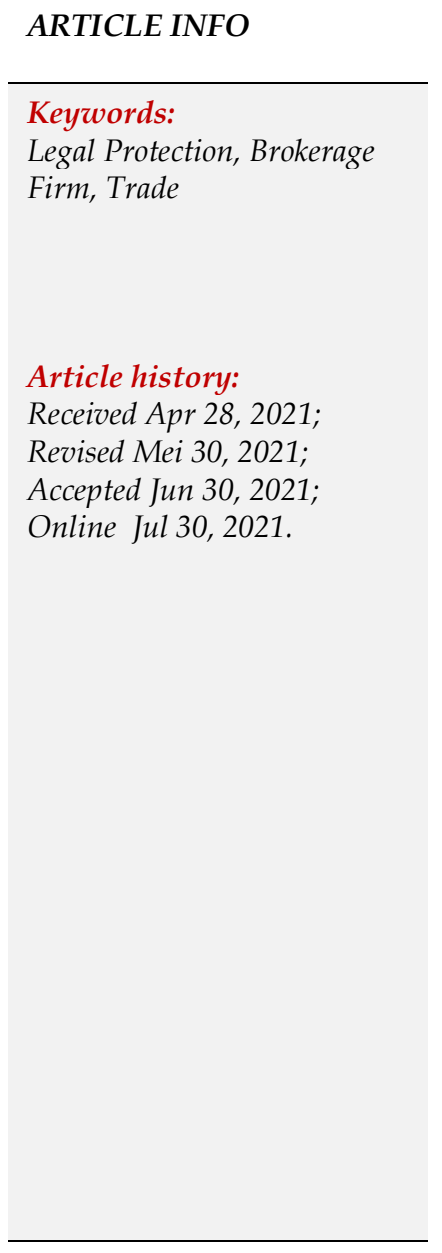

\begin{abstract}
This thesis discusses the legal protection of brokerage company customers against commodity futures trading in terms of Law Number 10 of 2011 concerning commodity futures trading, to determine the role of brokerage companies in conducting commodity futures trading transactions and to determine aspects of legal protection provided by brokerage companies. to the agreement that has been made between the brokerage companies in this case is PT..Kontak Perkasa Future and customers/investors; and to know the legality and supervision in the futures trading transactions to customers, business people, to the general public, and especially to futures brokerage companies in Indonesia. This study uses normative juridical research, which is a form of research that describes the applicable laws and regulations associated with legal theories and positive law enforcement practices, which are related to the problems investigated. The data collection techniques that the author uses in this research are interviews, literature study, direct observation or field observation. With the existence of a free market, the freedom of consumers (in this case customers in the Futures trading sector) to choose products and services from a Futures brokerage company is increasingly open. On the other hand, this condition can result in the position of business actors (in this case Futures Brokers) and consumers (customers) becoming unbalanced. The customer is in a weak position and becomes the object of business activity to achieve the maximum profit by business actors (Futures Brokers). The main factor that becomes the weakness of consumers (customers) is that the level of customer awareness of their rights is still very low, plus not all futures brokerage companies that appear have a business license from CoFTRA, therefore a legal protection is needed for brokerage company customers in Indonesia. Commodity futures trading as regulated in Law Number 10 of 2011.
\end{abstract}

This is an open access article under the CC BY-NC license.

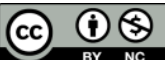

\section{Introduction}

Futures Trading is one of the new forms of investment where investors have the opportunity to get large profits, with this potential profit futures trading, which is a relatively new type of investment in Indonesia, attracts public interest. The amount of public interest in the futures trading industry directly or indirectly causes the emergence of many futures brokerage companies, unfortunately not all futures brokerage companies that appear have a business license from CoFTRA, therefore a legal protection is needed for brokerage company customers in commodity futures trading. 
The economic and financial crisis repositioned the urgency of the Indonesian futures market which was very late compared to other countries that had started trading since last century. As a result of the above constraints, the socialization of the need for a futures market has been neglected.

Article 1 number 1 of Law Number 10 of 2011 in conjunction with Law Number 32 of 1997 concerning BAPPEBTI states: "Commodity futures trading, hereinafter referred to as futures trading, is everything related to the sale and purchase of commodities with margin withdrawal and with subsequent settlement based on futures contracts, sharia derivative contracts, / other derivative contracts."

Commodity futures contract is a permanent commitment to deliver or receive a certain number of commodities with a predetermined quality throughout the period before maturity and the price is formed through an open auction continuously on the futures exchange. Globalization and commodity liberalization require the Government to anticipate commodity price fluctuations, Indonesia must design a special risk management structure to accommodate not only price risk but also other risks associated with commodities. The community must take advantage of all available alternatives for risk management including all forms of insurance protection which include price fluctuations, crop insurance, climatic conditions and the use of financial instruments.

The need for the use of futures markets is getting bigger in the face of free markets and globalization. On this basis, the government then issued a regulation regarding futures trading in 1997, issued Law Number 32 of 1997 concerning Commodity Futures Trading (BAPPEBTI) which has now been amended by Law Number 10 of 2011 which provides arrangements and regulations in general. and regarding futures trading in Indonesia.

Law Number 10 of 2011 also regulates the parties involved in futures trading, including the commodity futures trading supervisory agency (BAPPEBTI) which is the highest supervisor, the futures exchange is the party that organizes and provides systems and/or facilities for activities. futures trading, futures clearing institution as the party that organizes and provides systems and/or facilities for clearing and guarantees futures trading transactions, futures broker as the party transacting for the benefit of customers, and futures trader as the party conducting transactions for their own account.

For the futures exchange, Indonesia currently has 2 (two) futures exchanges, namely PT. Jakarta Futures Exchange (JFX) and PT. Indonesian Commodity and Derivatives Exchange (ICDX). For futures clearing institutions, there are currently 2 (two) futures clearing institutions, namely PT. Indentrust Security International (ISI). Commodity futures trading is different from trading in the capital market. Basically the futures market is the primary market, because the price is determined by the commodities whose contracts are traded on the stock exchange, while the capital market is the secondary market, because the price depends on the performance of the company (going public) whose shares are traded.

Another difference can be seen from its purpose. The capital market is held with the aim of mobilizing funds from a company by selling company shares, while futures trading is held with the aim of transferring risk from price fluctuations. In terms of the form of trading, in the capital market what happens is physical trading where there is a physical sale and purchase of shares, resulting in a physical handover of shares with the obligation to pay $100 \%$ of the transaction, while futures trading traded is a promise or agreement to deliver or receiving a certain item at a later date, the seller and buyer in the futures market are required to submit a certain amount of funds, about $5-10 \%$ of the value of the commodity being traded as margin. 
As a means of hedging, futures trading has a high risk high return characteristic. The possibility of customers to benefit from futures contract transactions is as large as the possibility of losses. The customer may suffer the loss of all the funds that have been deposited. The usefulness of the futures market is the same as it was a century ago: it provides an efficient and effective mechanism for price risk management for producers and consumers of commodities by protecting their risks from being taken over by speculators. It is clear that without speculators the market will be less enthusiastic, and the market will live if there are many locals, i.e. futures trading that takes risks from commodity producers and users with a view to making significant profits, by analyzing the market carefully.

Law Number 10 of 2011 and its implementing regulations have also provided regulations regarding protection of customers, including procedures for granting permits for futures brokers, regulations regarding the Know Your Customer principle, the obligation to deposit funds into separate accounts, managing separate accounts, mechanism for channeling orders, as well as sanctions in case of violation of regulations.

Law Number 10 of 2011 and its implementing regulations have also provided regulations regarding protection of customers, including procedures for granting permits for futures brokers, regulations regarding the Know Your Customer principle, the obligation to deposit funds into separate accounts, managing separate accounts, mechanism for channeling orders, as well as sanctions in case of violation of regulations. In addition, Law Number 10 of 2011 also regulates the settlement in the event of a civil dispute between the parties in futures trading. All of these provisions aim to provide protection to customers. Although the laws and regulations in the field of futures trading provide such rules as an effort to provide protection for customers, in practice many customers feel dissatisfied or disadvantaged in transactions.

\section{Method}

In compiling this thesis, normative juridical research is used, which is a form of research that describes the applicable laws and regulations, associated with legal theories and the practice of implementing positive law, which relates to the problems investigated. In this study, not only data processing and compilation is carried out, but what is more important is the analysis and interpretation of the data that has been obtained so that the meaning is known. In practice, this research is a field research, so that this research is expected to be able to solve problems regarding legal protection for brokerage company customers against commodity futures trading at PT. mighty future contact that the author is researching.

Normative research ${ }^{17}$ is a legal research method that is carried out by examining library materials or secondary data. Based on the objectives to be achieved in this study, the approach method used in this research is the empirical juridical approach. ${ }^{18}$ The juridical approach is used to analyze various laws and regulations that contain provisions regarding matters relating to the legal protection of brokerage company customers against commodity futures trading in terms of Law Number 10 of 2011 (case study at PT.Kontak Perkasa Futures, Branch Pekanbaru), while the empirical approach is used not merely as a set of normative laws and regulations, but the law is seen as community behavior, always interacting and relating to social aspects, such as politics, economy, social and culture.

\section{Analysis And Results}

\subsection{Regulations For Legal Protection Of Customers In The Field Of Commodity Futures Trading}

a. Protection for Prospective Customers in the Pre-Deal Stage of Futures Trading. 
Based on the Regulation of the Head of the Commodity Futures Trading Supervisory Agency Number: 63/BAPPEBTI/Per/9/2008 and 64/BAPPEBTI/Per/9/2009 concerning Technical Provisions for Futures Broker Behavior, it is stated that:

Article 1

1) Business activities as Futures Broker can only be carried out by Futures Exchange Members in the form of a limited liability company that has obtained a Futures Broker business license from CoFTRA.

2) The implementation of business activities as referred to in paragraph (1) is carried out by individuals who have obtained a Futures Broker Representative permit from CoFTRA.

3) The Futures Broker Representative as referred to in paragraph (2) must have the status as a permanent employee of the relevant Futures Broker in accordance with the prevailing laws and regulations in the manpower sector.

Articel 2

1) Only Futures Broker Representatives are authorized to deal directly with potential Customers or Customers in the context of carrying out Futures Contract transactions.

2) Direct contact as referred to in paragraph (1) is to have contact with potential Customers or Customers face-to-face directly or through electronic means without going through other parties.

3) The scope of authority of Futures Broker Representative in dealing directly with potential Customers as referred to in paragraph (2).

Article 3

1) In dealing directly with potential Customers, Futures Broker Representatives must:

a) Knowing the background of the prospective Customer which includes knowledge, transaction experience in the Futures Trading field and financial capability so that it is obtained confidence that the prospective Customer who will be accepted is a worthy prospective Customer;

b) Submit and explain the Company Information document in the form of a company profile that has been approved by CoFTRA, the contents of which are guided by Form Number: IV.PRO.9.;

c) Submitting and explaining the Risk Notification document using Form Number: IV.PRO.10., Mandate Granting Agreement document using Form Number: IV.PRO.11., as well as Trading Rules as evidenced by a statement that the Futures Broker Representative has explained and the prospective Customer has understood the explanation of the Futures Broker Representative by using Form Number: IV.PRO.12.;

d) Explaining the Futures Contract to be transacted;

e) Submit and explain the Transaction Account Opening Application document, and check whether the document has been completely filled in completely by the Customer in accordance with Form Number: IV.PRO.13.;

f) Provide opportunities for prospective Customers to simulate Futures Trading transactions, as evidenced by a statement that the potential Customers have simulated Futures Trading transactions using Form Number: IV.PRO.14.;

g) Provide opportunities for prospective Customers to read and study the contents of the Risk Notification document and the Mandate Granting Agreement document;

h) Signing the Risk Notification document by using Form Number: IV.PRO.10.; and

i) Sign the Mandate Granting Agreement document using Form Number: IV.PRO.11

2) The Mandate Granting Agreement as referred to in paragraph (1) letter i must be signed by the Futures Broker Representative, Customer, and Futures Broker Company Head at the Head Office or the relevant Futures Broker Branch Office.

3) Futures Broker Representative who is also one of the Futures Brokerage Company Leaders at the Head Office or Futures Broker Branch Office may only sign the Mandate Granting 
Agreement document as Futures Broker Representative or Futures Brokerage Company Leader.

Article 4

In dealing directly with potential Customers or Customers, Futures Broker Representatives who carry out the business activities of the Futures Broker as referred to in Article 1 paragraph (2), are prohibited from:

1) Accepting a potential customer if he knows the prospective customer in question:

a) Has been declared bankrupt by the court;

b) Has been declared to have violated the provisions of this Law and/or its implementing regulations by the judiciary or CoFTRA;

c) Official or employee:

d) CoFTRA, Futures Exchange, Futures Clearing House; and

e) Treasurer of an institution that serves the public interest, unless the person concerned is authorized by the institution.

2) Directly or indirectly influencing prospective Customers or Customers by providing misleading information to conduct Futures Contract transactions, including: offering fixed income or profit sharing;

3) Offering Futures Contracts that are not approved by CoFTRA;

4) Accepting Customers whose sources of funds come from several people who are combined in one account;

5) Receive customer funds (initial margin) in cash (cash);

6) Receive customer funds (initial margin) before signing the Risk Notification document and the Mandate Granting Agreement document;

7) Receive customer transaction access code (Personal Access Password);

8) Make an agreement in any form with a potential Customer or Customer except the agreement regulated in this Regulation; or

9) Receive authorization from the Customer to conduct transactions on behalf of the Customer concerned.

Article 5

1) Futures Brokers are responsible for actions taken by Futures Broker employees or parties related to the Futures Broker in carrying out Futures Trading activities.

2) In carrying out Futures Trading activities, Futures Brokers are required to:

a) Establish a unit that functions to provide training on futures trading to prospective customers;

b) Create training materials on futures trading approved by CoFTRA;

c) Establish a unit that functions to provide customer complaint services and oversee compliance with regulations;

d) Create and implement standard operating procedures (POS) regarding customer service approved by CoFTRA;

e) Provide facilities for direct or indirect transactions;

f) Provide a separate trading room from the settlement room;

g) Explain the meaning and function of a segregated account;

h) Explain that customer funds must be transferred or deposited into a segregated account;

i) Explain the fees that will be charged to customers;

j) Explain alternative settlements of civil disputes, especially regarding financial disputes;

k) Carry out standard operational procedures (postal) for customer acceptance and implementation of transactions determined by futures brokers and approved by 


\section{CoFTRA;}

1) Record and record the receipt of orders from customers in the card by using form number: iv.pro.15. And confirming to the customer about the transaction that has been carried out by using the form number: iv.pro.16., in the event that the delivery of the transaction is done indirectly by the customer; and

m) Submitting daily customer reports (daily statements) to customers.

Article 6

In carrying out Futures Trading activities, Futures Brokers are prohibited from:

1) Employing foreign workers (not Indonesian citizens);

2) Looking for potential customers under the pretext of job vacancies;

3) Receive the Customer's initial margin deposit in cash;

4) Submit the Customer's transaction access code (Personal Access Password) to a party other than the Customer;

5) Receiving a Margin deposit for a Customer account whose sender's identity is not the same as the identity of the Customer stated in the Mandate Granting Agreement document;

6) Providing loan funds for Margin Customers;

Article 7

Futures Brokers employees or other parties who have an interest in Futures Brokerage Companies are prohibited from:

1) Receive a power of attorney in any form from a potential Customer or Customer;

2) Directly or indirectly influencing potential Customers or Customers by providing misleading information to conduct Futures Contract transactions, including: offering fixed income or profit sharing;

3) Make an agreement in any form with a potential Customer or Customer except the agreement regulated in this Regulation;

4) Receive and use the Customer's transaction access code (Personal Access Password);

5) Make or publish untrue statements whose contents are not in accordance with the laws and regulations in the Futures Trading sector; or

6) Receive the Customer's Daily Report (Daily Statement).

7) Overbooking the Customer's funds from the Futures Broker's Segregated Account to the Customer's account whose name does not match the name and bank account listed in the Mandate Granting Agreement document;

8) Make payments in cash in the event the Customer withdraws his funds (withdrawal);

9) Assigning transaction settlement staff to double as staff

10) Executing transactions (dealing) and/or vice versa;

11) Using the Customer's funds contained in the Segregated Account for other purposes except to pay commissions and other fees in connection with Futures Contract transactions; or

12) Submitting the Daily Statement of the Customer to other parties except the Customer or his proxies.

b. Protection For Customer In Stage Implementation Transaction Futures Trading

Based on the Government Regulation of the Republic of Indonesia Number 9 of 1999 concerning the implementation of commodity futures trading, it is stated that:

Article 108

1) Whenever receiving a Customer's mandate to make a transaction at the expense of the Customer's account, the Futures Broker must record it on the mandate card as determined by CoFTRA.

2) If the Customer's order as referred to in paragraph (1) is delivered by telephone, then the 
orders and conversations must be recorded.

3) If the transaction has been completed, the Futures Broker shall immediately notify the Customer concerned no later than the next 2 (two) working days.

4) Futures Brokers are required to submit to CoFTRA the calculation formula for the transaction or service fees that must be paid by the Customer for reference. ${ }^{129}$

Article 110

In distributing Customer's orders, Futures Brokers are prohibited from doing the following:

1) Hiding or changing information about Commodity Futures Trading;

2) Suggest to buy or sell certain types of Futures Contracts or provide an assessment that prices will increase or decrease without being based on correct calculations with the intention that the Customer makes transactions;

3) Receiving orders from customers and completing agreements for granting orders outside the head office and official branch offices;

4) Divulge secrets about Customer orders or other business secrets obtained in the execution of transactions;

5) Misappropriating the Customer's funds;

6) Providing incorrect answers to the Customer's questions, thereby harming the interests of the Customer;

7) Create, store, report and publish against the law about its activities, or make false statements in accounts, financial statement books, and other documents required by the applicable laws and regulations;

8) Failure to submit various reports required by applicable laws and regulations;

9) Giving loans or borrowing money from the Customer or acting as an intermediary for the Customer to lend or borrow money from other parties;

10) Make a recording error regarding the implementation of the transaction;

11) Make unauthorized changes affixed to the timestamp on customer orders, transaction reports, or other documents;

12) Carry out transactions exceeding the maximum limit that has been set.

13) Carry out transactions for its Customers without orders from the relevant Customers;

14) Not channeling the Customer's mandate to the Futures Exchange in accordance with the Customer's orders;

15) Receive authorization from the Customer to conduct transactions on behalf of the Customer concerned, except in certain circumstances stipulated by CoFTRA; and

16) Violating other provisions regulated in the applicable laws and regulations. ${ }^{130}$

Based on the Regulation of the Head of the Commodity Futures Trading Supervisory Agency Number: 64/BAPPEBTI/Per/1/2009 concerning the Technical Provisions for the Behavior of Futures Brokers, it is stated that:

Article 5

1) Futures Brokers are responsible for actions taken by Futures Broker employees or parties related to the Futures Broker in carrying out Futures Trading activities.

2) In carrying out Futures Trading activities, Futures Brokers are required to:

a) Create and implement standard operating procedures (POS) regarding customer acceptance procedures approved by CoFTRA;

b) Establish a unit that functions to provide training on futures trading to prospective customers;

c) Create training materials on futures trading.

d) Explain the meaning and function of a Segregated Account;

e) Explain that the Customer's funds must be transferred or deposited into a Segregated Account;

f) Explain the fees that will be charged to the Customer; 
g) Provide Futures Trading transaction simulation facilities for potential Customers;

h) Create and implement Standard Operating Procedures (POS) regarding the implementation of transactions determined by Futures Brokers and have been approved CoFTRA;

i) Provide a separate trading room from the settlement room;

j) Provide facilities for direct or indirect transactions;

k) Record and record the receipt of orders from the Customer in the Mandate Card by using Form Number: IV.PRO.15.;

1) Confirming to the Customer about the transaction that has been carried out by using Form Number: IV.PRO.16., in the event that the delivery of the transaction is done indirectly by the Customer;

m) Submit a Daily Transaction Report (Daily Statement) to the Customer;

n) Explain alternative settlements of civil disputes, especially regarding financial disputes.

o) Create and implement Standard Operating Procedures (POS) regarding the handling of customer complaints by Futures Brokers and have been approved by CoFTRA; and

p) Establish a unit that functions to provide customer complaint services and oversee compliance with regulations.

\section{c. Protection for Customers in the Post Futures Trading Transaction Stage.}

Based on the Government Regulation of the Republic of Indonesia Number 9 of 1999 concerning the implementation of commodity futures trading, it is stated that:

Article 92

1) Futures Brokers are required to make, maintain, and keep all financial records correctly and in accordance with generally accepted accounting principles and available at any time for inspection, and transaction records including all cards, memos or records relating to Futures Contract transaction activities, options, and commodities in the physical market.

2) The records as referred to in paragraph (1) include all orders that have been transacted, transaction cards, signature cards, transaction log books, journals, cash books, canceled checks, copies of information, copies of sale and purchase statements, Mandate Granting Agreement Documents, Documents Risk Notice, and other records made in relation to the execution of Futures Contracts, Commodity Options transactions in the physical market.

3) For Option transactions, information must be recorded regarding the time of the transaction, buy or sell Option transactions, maturity time, number of transactions, type of Option, benchmark price, premium, commission, and other fees.

Article 93

1) The Futures Broker receiving the mandate must immediately record on the mandate card, the name of the Party giving the mandate, account number and data of the mandate.

2) The mandate card as referred to in paragraph (1) must be immediately marked with the time of receipt of the mandate by using a time-keeping equipment or machine.

Article 94

1) Futures Brokers are required to make separate financial records for each Customer, including incoming and outgoing money and all Contract transactions Futures in the domestic and/or foreign Futures Exchange which includes time, price, number of transactions, and type of commodity.

2) Futures Broker is required to submit confirmation of the Customer's financial position, including various costs incurred for transactions and services to the Customer every day, no later than 12.00 on the day next.

3) Futures Brokers are required to confirm at least 1 (one) month to the Customer regarding 
the open position of the Futures Contract and the resulting price, unrealized net profit or loss, all Customer funds, and various fees charged to the customer's account. ${ }^{134}$

\section{d. Guarantees Provided by Brokerage Companies to Customers/Investors in Relation to} Consumer Legal Protection.

Customers are consumers so that protection for their interests is a demand that should not be ignored. In the world of futures trading transactions, the customer / investor is an element that plays a very important role, because the life and death of the world of transactions relies on the trust of the customer or the community, The definition of consumers in article 1 number (2) of Law Number 8 of 1999 concerning consumer protection, namely:135 Consumers are every person who uses goods and/or services available in the community, both for the benefit of themselves, their families, other people, and other living creatures and not for trading.

Meanwhile, customer/investor article 1 wish (22) of Law Number 10 of 2011 concerning commodity futures trading can be interpreted as follows: Customer is a Party that conducts Futures Contract transactions, Sharia Derivative Contracts, and/or other Derivative Contracts through accounts managed by Futures Brokers. The guarantees provided by the company to customers as stated in Article 1 to Article 6 of Law Number 10 of 2011 concerning Commodity Futures Trading are as follows: Guarantee funds can only be used for the purpose of paying compensation to customers caused by breach of contract made by futures brokers in connection with the distribution of customer orders for foreign exchange futures contract transactions.

Article 69

1) Futures Exchange is required to establish a Special Unit to manage the Compensation Fund.

2) The Special Unit as referred to in paragraph (1) is responsible to the Futures Exchange.

3) The Compensation Fund must be kept in an account created specifically to store the Compensation Fund at a Bank approved by CoFTRA.

4) The accounting for the Compensation Fund is separate from the bookkeeping of the Futures Exchange.

5) Compensation Fund financial statements must be examined and audited by a Public Accountant.

6) No later than 3 (three) months after the end of the financial year, the Futures Exchange is required to submit the financial report of the Compensation Fund as referred to in paragraph (5) to CoFTRA.

The definition of standard clause is contained in Article 1 point 10 of Law no. 8 of 1999 concerning Consumer Protection, namely any rules or conditions and conditions that have been determined in advance unilaterally by business actors as outlined in a document and/or agreement that is binding and must be fulfilled by consumers. What is standardized in the agreement are the clauses, not the agreement form. At this time, the position of the customer is so weak that he just accepts the rules and conditions by the futures brokerage company.

It turned out that in carrying out commodity futures trading transactions at PT. Konak Perkasa future Pekanbaru not only provides benefits to customers, but there is also a loss to the customer/investor itself, and this happens when the customer does not fully understand how the futures brokerage company he invests his funds in. Because most of the futures brokerage companies sell their brokerage services in Indonesia, at this time mainly conventional futures brokers, both large and small scale brokerage companies. Each brokerage company competes to provide the best service to customers. Not even a few brokerage companies that promise big profits for their customers, if the customer becomes an investor and invests through the services of the brokerage company. 
In this chapter, PT.Kontak Perkasa Future contains or gives tips on how to choose a futures broker that is so many for each customer as a consideration for customers in making their decisions to invest their capital, namely:

First and foremost, of course, it depends on how the customer responds well, however, there are good principles to adhere to in choosing a futures broker, especially for the initial assessment, namely the cheaper the fees or commissions offered by the brokerage company, usually the services provided are incomplete, on the contrary. Futures brokerage companies that use expensive fees usually provide better services and facilities.

\section{Conclusion}

From the descriptions in the previous chapters, the following conclusions can be drawn: Law Number 10 of 2011 regulates the parties involved in futures trading, including the commodity futures trading supervisory agency (BAPPEBTI) which is the highest supervisor, the futures exchange is as parties who organize and provide systems and/or facilities for futures trading activities, futures clearing institutions as parties that organize and provide systems and/or facilities for clearing implementation activities and guarantee futures trading transactions, futures brokers as parties who transact for the benefit of customers, and futures trader as the party who makes transactions for his own account.

Futures trading offers many opportunities for investors with capital and risk involved. Futures speculators who invest in commodity futures are the same as those who invest in stocks, bonds and property, namely taking profits by taking risks, of course with the expectation of profiting from price movements.

Futures trading as an alternative form of investment and a means of hedging is a trading mechanism that is high risk high return. On the one hand, customers who invest in futures trading (either hedgers or speculators) have the opportunity to earn large profits. However, on the other hand, there is an inherent risk where due to fluctuating market conditions the customer may lose all of the funds invested and it is possible for the customer to be asked to add more funds. This large risk factor makes customers in the field of futures trading need protection, especially legal protection, so that their rights as customers are considered.

A rule of law must be able to apply efficiently and effectively in society. In practice, the regulations in the field of futures trading which are intended to provide protection for customers cannot be said to be applied efficiently and effectively.

\section{References}

Az. Nasution. An Introduction to Consumer Protection Law. Jakarta. Edited Media. 2001.

Diamond Charisma Heli. Getting to Know Foreign Exchange. Yogyakarta. Gajah Mada University Press. 2000.

Bungin. Qualitative Research. Jakarta. Prenada Media Group, 2007

Fred F. Kerlinger. Principles of Behavioral Research. Yogyakarta. Gajahmada University Press, Fifth Printing, 1996.

HB Sutopo, qualitative legal research methodology. Surakaarta: UNS Press, 1998.

Kristiyanti, Celina Tri Siwi. Consumer Protection Law. Jakarta: Sinar Graphic, 2000. 
Lucius M, S and Indrawati Yulika. Forex Trading Guide. Yogyakarta. Andi. 2006.

Lumban Rock, Quick. Futures Trading (Futures Trading). Jakarta: Elex Media Komputindo, 2010.

Magerita. Legal Protection Against the Purchase of Pawned Shares. Medan. USU Press. 2010.

Nasarudin Irsan et al. Legal Aspects of the Indonesian Capital Market. Jakarta. date. 2010.

Purba Hasim. A Guide to Understanding Legal Studies. Medan. Light of Science. 2006.

Sawidji Widoatmodjo. How to Quickly Start Investing in Stocks. Jakarta. PT. Elex Media Komputindo, 2004.

Soekanto, Soerjono. Introduction to Legal Research. Jakarta. UI-Press Publisher. 2012.

Sofia Hanapi. Futures Trading and Indonesian Economy. Jakarta. PT. Alex Media Kompetindo. 2000.

Sophie Joseph. Consumer protection. Bandung. PT. Image of Aditya Bakti. 2003 Sidabalok Janus. Consumer Protection Law in Indonesia. Bandung. PT.

Image of Aditya Bhakti. 2006.

Subekti. Principles of Civil Law. Jakarta. Intermass. 2001

Subect. Legal agreement. Cet.14. Jakarta. Intermediate. 1992

Vibby Santo. The Stock Market Secret Profit of When Buy and Sell Candlesticks can Tell. Jakarta 2012

Wahyuni Sri Endang. Legal Aspects of Certification and Its Relation to Consumer Protection. Bandung. PT. Image of Aditya Bhakri. 2003.

Wijaya Krishna. National Banking Reform. Jakarta. Compass Daily. 2000 Wijaya, Johanes Arifin. Futures Exchange, Yokyakarta : Andi Yokyakarta, 2002.

CoFTRA. Regulation of the Head of CoFTRA concerning Amendments to the Regulation of the Head of CoFTRA Number 63/BAPPEBTI/Per/9/2008 concerning Technical Provisions for Futures Brokers' Behavior. Regulation of the Head of CoFTRA Number 64/BAPPEBTI/Per/1/2009.

Presidential Decree Regarding Commodities That Can Be Subjected to Futures Contracts. Presidential Decree No. 119 of 2001.

Civil Code [Burgerlijk Wetboek]. Translated by Subekti Jakarta: Pradnya Paramita, 2001.

Government Regulation Regarding Commodity Futures Trading Implementation. PP No. 9/1999, LN No. 16/1999, TLN Number 3805.

Regulation of the Head of CoFTRA on Derivative Contracts Traded in the Alternative Trading System. Regulation of the Head of CoFTRA Number: 72/BAPPEBTI/Per/9/2009.

Regulations concerning Procedures for Channeling Customer Mandates to Foreign Futures Exchanges. Regulation of the Head of CoFTRA Number: 82/BAPPEBTI/Per/04/2010.

Regulation of the Head of CoFTRA on Procedures for Implementing Promotional or Advertising Activities, Training, and Meetings in the Commodity Futures Trading Sector. Regulation Head CoFTRA Number: 83/BAPPEBTI/Per/06/2010.

Law Number 10 of 2011 concerning Commodity Futures Trading. Law No. 79 of 2011, TLN No. 5232 